\title{
Funding and Management Support for the Recovery of Micro, Small and Medium Enterprises During the Disruption of the COVID-19
}

\author{
Antoni \\ Universitas Wijaya Putra, Indonesia \\ Corresponding author email: antoniderasap@gmail.com
}

\begin{abstract}
This study analyzes financial and management support for the recovery of MSMEs after the COVID-19 pandemic in Indonesia. Small businesses' development is expected to drop about conditions of funding and management in line with the national pandemic response policy. To answer this problem, we have carried out various data collection techniques, including introductory reading, literature review of publications, and other documentation. Then analyze with a phenomenological approach through critical analysis, explain what we get through keyword searches to find literature, evaluate, identify themes, determine structures, and draw conclusions. The critical analysis process for the validity and reliability of the answer findings ensures that the findings have answered this study's questions. By paying attention to existing data and analysis results, it can be concluded that small business activities receive funding and management support from the government as a stimulus effort after being faced with various difficulties. These publications' findings prove the seriousness of governments in several countries and local governments to help small businesses survive during the pandemic and after the outbreak. Thus, this study's results will be meaningful input for all stakeholders in the world of MSMEs.
\end{abstract}

Keywords---business prediction, financial development, pandemic COVID-19 disruption, small business management.

\section{Introduction}

In facing the impact of government policies, namely limiting access and public crowds in minimizing the spread of the Coronavirus pandemic, Small, and Medium Enterprises (MSMEs) is the worst one among businesses in the field that they need to be supported and strengthened so that they can survive, benefit, and even be sustainable in the future. Moreover, small business activities are no longer seen as an alternative but as the backbone or foundation of their economy. Kumar et al. (2015), said that MSMEs could replace their products with other products when they cannot produce them. It means that other parties can support them to get up and rebuild their small business activities after they experience economic disruption and other crises (Haddud et al., 2017). That is, MSMEs kept the national economy afloat until now, even though it was stumbling after being hit by various crises. Every party with the ability must support to bring positive effects and healthy solutions during and after the pandemic phase of the program, disrupting the sustainability of micro-businesses and cooperatives. The reason is that this sector is one of the sectors most affected by the pandemic and other crises. It has been proven that this pandemic has disrupted supply and demand and supply chains so that the economy at the regional, national, and even international levels has stalled. (Singh et al., 2020; Putra et al., 2020; Aslan et al., 2020).

As explained by Napitupulu et al. (2018), MSMEs are the spearhead of the national economy. Because the contribution of these small economic activities to Indonesia's Gross Domestic Product continues to survive even though the country's current economic conditions are still at the time of the pandemic, it can be attributed to the very high employment of the business and continues to grow, reaching $76.99-87.22$ percent with the number of them reaching 62 million or around 98 percent of national business actors (Saputri \& Wijaya, 2018; Setyawan \& Wulandari, 2020). The numbers and presentation of MSMEs' existence in this country prove that they need to be maintained and predictable for the direction and development of financial management and governance in the postpandemic period. Furthermore, Saputri \& Wijaya (2018), said that small businesses with the right criteria have 
financial governance. They found three categories of sound financial management; fair enough, moderate, and not reasonable. Those in the medium category who continue to be easily found still survive, and they belong to medium financial literacy. The financial literacy factor has an impact on the financial management of this small business. In other words, the higher their financial literacy, the more sustainable their business financial management will be.

Resilience as the spearhead of the national economy, the government has placed MSMEs as the top priority for beneficiaries in the national economic recovery since the beginning of the pandemic. When viewed since the emergence of the COVID-19 pandemic, this small business is the sector most affected by government policies when controlling this dangerous pandemic. For example, based on a survey of 202 business actors in bread, biscuits, cake, market snacks, noodles, pancakes, and pastry in big cities such as Surabaya and Jakarta, Thaha (2020), said that the impact of the pandemic on MSMEs in many big cities. Thaha said that around 90 percent of those affected by the people's business felt the risk. Marlinah (2020), successfully studied the opportunities and hopes, and challenges for MSMEs to maintain and continue their economy in 2020 when it was in a pandemic period. Meanwhile, the creative economy's state program has budgeted around IDR 123.46 trillion in funds for small businesses, the national economic recovery program. As of July 30, 2020, funds for these people's businesses have been distributed around 22.50 percent or IDR 27.86 trillion (Pakpahan, 2020; Sugiri, 2020; Nasution, 2020).

Suppose looking at the seriousness of the government in helping capital for the continuation of MSMEs. In that case, Muhyiddin (2020), revealed that both the Covid-19 period entered the New Normal and entered a planning period to increase development in the country. He added that the government could say that providing working capital allocates low-interest working capital credit through state money placement in the form of deposits and government demand deposits at partner commercial banks. For example, the government places IDR 30 trillion in partner commercial banks in the short term. This allocation of government funds is carried out to accelerate credit provision, especially for MSMEs and other labor-intensive industries, to accelerate the lower class's economic recovery after being affected by COVID-19. This policy is regulated in the Minister of Finance Regulation Number 70/ PMK.05/ 2020 concerning Placement of State Funds in Commercial Banks in accelerating the people's economic recovery, which was updated with PMK Number 104/ PMK.05/ 2020. The state establishes four criteria for partner commercial banks to be allocated funds: Commercial bank business licenses are still valid, Business activities are located in Indonesia, and most owners are Indonesian citizens / legal entities / the government, The OJK has verified the minimum health level of composite three, We are carrying out banking activities that support PEN's acceleration, namely credit expansion to cooperative - MSMEs debtors and providing financial support to financial institutions that expand credit to cooperative-small business debtors (Hansemark, 2003; Wu, 2010).

Of the total costs allocated for handling COVID-19 from 1999 to 2020 amounting to Rp 695.2 trillion, amounting to Rp123.46 trillion (or 17.75\%) is allocated specifically for support MSMEs. Fiscal assistance for small businesses can be seen in the table below. Based on the data above, then the amount is allocated to six activities, namely interest subsidies amounting to IDR 35.28 trillion, placement funds for the restructuring of Rp78.78 trillion, expenditure for services underwriting of IDR 5 trillion, MSMEs final PPh is borne government (DTP) of IDR 2.4 trillion, as well as investment financing to cooperatives through the Institute Cooperative Revolving Fund Manager, Micro Small and Medium Enterprises of 1 trillion rupiahs.

Table 1

Types of program assistance

\begin{tabular}{ll}
\hline Interest subsidy & 35.28 trillion \\
Placement of Funds for Restructuring Credit & 78.78 trillion \\
Expenditures for Guarantee Services Fee & 5 trillion \\
Guarantee for Working Capital & 1 trillion \\
The government bears final Income Tax & 2.4 trillion \\
Investment Financing to Cooperatives through the LDPB & 1 trillion \\
Total & 123.47 Trillion \\
\hline
\end{tabular}

Source: Kompas, compiled, 2020

\section{Method}

This business study's main objective is to analyze and understand the government's policy and seriousness in funding and management support for the recovery of MSMEs after the COVID-19 pandemic in Indonesia. To answer these problems, we have taken a series of data searches and analyses to understand how the government has thoughtfully provided funding and management support to recover and develop small businesses, including preliminary reading, 
literature review of international publications, and other documentation. After the data is collected, analyze it with a phenomenological approach through critical analysis of data and information, report what we find through keyword searches from much literature, evaluate the theme, determine the reporting structure, and organize reports (Fanelli, 2009). In conducting critical analysis, we emphasize the principles of validity and reliability of analysis findings and ensure that the analysis results have answered the essence of the formulation of this study's questions.

\section{Result}

Sugiri (2020), examined how the government has saved MSMEs from the result of the pandemic crisis. He added that the government had made many efforts to support small entrepreneurs from the COVID-19 epidemic disruption. They can survive being hit by a pandemic policy and map the long run strategies needed to complement the policy. At the end of his study, he said that government policy was adequate to save small businesses during and after the pandemic. It is essential to be supported by various strategies to maintain these people's businesses' sustainability as one of the actors in saving the national economy.

The government's MSME recovery efforts were also reviewed by Marlinah (2020), who examined various programs to help the national economy through people's small businesses when COVID-19 hit their businesses. This economic recovery through the Ministry of Finance has succeeded in distributing tax incentives to taxpayers, minimal business actors. This effort was carried out as a response from the state, which is very meaningful for businesses that can support the national economy. His study revealed that the productivity of these small business actors has automatically affected economic stability and decreased the amount of state revenue. Developing countries often use tax incentives to attract investment to their countries, including Indonesia. However, during the COVID-19 pandemic, the government has made encouraging regulations in the form of final PPh incentives for MSMEs borne by the government. However, as a counterweight, small business actors must also make other creative and innovative efforts to maintain their business because basically, the support for tax incentives for small business aims to maintain the existence of businesses in several sectors that are heavily affected by pandemic disturbances as a stimulus for the recovery of the people's economy (Wu et al., 2007; Arend \& Wisner, 2005).

Meanwhile, another study conducted by Blandina et al. (2020), analyzes the government's efforts and strategies to avoid the threat of an economic recession during a pandemic, the government's monetary and fiscal capacity to increase productivity, competition, and the world economy. According to Blandina, the government's role, together with business actors, plays a role in continuing innovation in the business world, including entrepreneurs with startup ideas and strategies and encouraging small and medium enterprises. This effort is part of the government's support efforts to increase national economic growth so that it continues amid the financial crisis due to the pandemic impact and policies that are often ineffective.

The same matter was done by Shafi et al. (2020), in Pakistan in the government's efforts to support small businesses that cannot escape the crisis of economic difficulties. The government's goal is to help its citizens from the impact of national policies to combat the coronavirus outbreak in the downturn of small community businesses, which are the majority of people's businesses. The conclusion is that small businesses of the people who have collapsed in business feel very helpful in bringing back some of the businesses that have been affected. On average, MSMEs in Pakistan have been severely affected; for example, problems with capital difficulties disrupted supply chains, decreased demand, and decreased sales and profits. Another problem is that more than $80 \%$ of people's businesses are not ready to anticipate the impact of COVID-19 on businesses. More than $30 \%$ of their microbusinesses explained that they could not stand up for the fight if the government continued to adopt policies that were not necessarily correct. They believe the results of this study are reliable with the findings of their previous study. Added various support policies aimed at anticipating the bitter impact of the outbreak on all types of MSMEs.

Studies related to government policies to support funding for MSMEs were also carried out by Taiwo et al. (2016), namely the MSME funding project and the value received for Nigeria's national economic recovery. (Humphery \& Freeman, 2018). In this regard, it is a global understanding that community-owned small businesses have become critical spearheads in times of difficulties and national economic transitions in developing countries. These small businesses hold a large share of nearly $100 \%$ of all Nigerian people's business activities, leading to employment and a significant domestic income. It is also what Kauffmann (2005), explained that supporting MSMEs has become an effective and strategic means of fighting poverty. Therefore, community MSMEs' role and financial support and governance is the only solution so that small businesses can contribute even in times of economic difficulty. Likewise, the economic study, especially SMEs by the World Bank, determined the seriousness of several donor countries and the World Bank for funding the people's business sector as a core and strategic sector to 
encourage economic improvement in each developing country with solutions to employment absorption and poverty reduction (World Bank, 2015).

In a similar study to support small businesses from collapse, Razumovskaia et al. (2020), assess the extent of Russia's national policies in helping small business entrepreneurs affected by the COVID-19 disruption. Razumovskala succeeded in developing a cognitive-econometric model to understand how the Russian government can help affected MSMEs during the pandemic - connected with the RSBI index prediction, the assessment of the effectiveness of design support from the government for MSME actors. With this study's design, they can determine how significant the change in policies for business activists in facing the severe crisis caused by the pandemic is to restore people's businesses' plight. The development of cognitive designs has proven useful by many parties, including the government, to continue to control and monitor the principles of the usefulness of Russian national policies that help small businesses. In this way, circles in Russia can use it as an alternative to assess the effects of anti-crisis measures since the pandemic hit Russia and cases of exogenous risks that can reduce the performance of MSMEs. The validity of this study's results is determined by utilizing an econometric method applied to empirically evaluate the suitability and level of positive effects of state actions on small businesses' sustainability in the uncertain pandemic era.

In the context of government policies to support small and medium enterprises from several countries hit by the COVID-19 disruption is so essential. The study of Goniewicz et al. (2020), examines how the European Union's action and management respond to the outbreak impact. Their study has succeeded in providing a new understanding of how heavy it is to the continuity of small and large businesses in several European Union countries. With this study, the parties get input in responding to governance again more effectively its impact. This study has also succeeded in suggesting various strategies to deal with the pandemic's impact. For example, the decision to tighten countries' borders, especially Europe, to slow down coronavirus transmission is also essential. This study supports the government's financial policies to protect workers and business people from supporting the return of the economic business system. With the complexity of the problems from the impact of the crisis on small businesses and the intensity of the distress caused by the pandemic, this study also discusses how global countries are related to business and health, thus making it possible for governments and businesses need to adapt to a new, open-ended approach to policy models that promote cooperation. Finally, we can explain that this study includes government management's capacity to provide input in the form of financial policies and monitor the sustainability of all types of small businesses in several European countries.

\section{Discussion}

Funding policies and management improvement support for MSME recovery actions during the financial crisis during COVID-19 are the main objectives of this business study. Government efforts shape small business policy, and protection and continuation recovery during a pandemic is a significant study theme to carry out due to the business community's difficulties in facing the economic impact of the pandemic and difficulties for the government. So giving priority to supporting people business with a large budget allocation is a solution offered by experts and the government itself.

In this regard, we have studied various government policies both in Indonesia and in many other countries. This study is essential to let more people understand how each government protects and restore people macro business impacted by pandemic. These small businesses have proven to have a significant role in supporting the national economy. The national policy to protect the small business was also proved by Moser \& Yared (2020), who saw the pandemic with distraction must be done with the government role, policy, and strong commitment. The Central Bureau of Statistics in 2019, the performance of small businesses occupied 99.9 percent of total business activities in a country with 62.9 million business programs based on Bank Indonesia.

Sondakh (2019), said that the MSMEs absorb 96.9 percent and contribute 60.34 percent to the national gross domestic product during the pandemic. The existence of business continued to dominate the domestic economy, significantly when imported goods were disrupted by suppliers, which had never happened before the pandemic. Thus, the existing small business activities can help overcome the unsustainable supply of community needs. However, this potential is not easily realized because the tap for importing raw materials is still open so that domestic production has not been maximally absorbed. It makes it difficult for business players to penetrate the domestic market for raw materials needed by residents. Rowan \& Galanakis (2020), found that pandemic challenges with considerable disruption in many small businesses can be solved using innovations and government policy.

From several publications that we have reviewed, both in-country and in-country studies, we can explain that the size of business in the category of gaining government support is all businesses that fall into the four criteria; micro, 
small, medium, and large enterprises based on their net worth and annual sales by each business actor. Businesses that run a simple average do not have a building for business and have the least annual income. So this category of business is included in the fostering and financial support of the government because they are very vulnerable to the effects of pandemics and other financial crises (Hadi et al., 2018). With the above criteria from some of the previous studies' findings, we can say that governments in many countries have tried to empower MSMEs to become small but resilient and independent businesses.

This form of empowerment from the government ensures that small businesses get the broadest possible partiality, certainty, opportunity, protection, and support for doing business. Apart from empowerment, the government supports all small businesses in development, financing, guarantees, and partnerships. The Indonesian government is currently handled explicitly by the Indonesian government through business and small business ministries in many countries and several other related ministries so that business continuity can be ensured during the pandemic. For example, the study of Febriana (2017), which raised the large role of state leaders in the regions in supporting SMEs in Sukamulya, Banyumas, Pringsewu Regency in the business of a sharia economic perspective in a study of business models of local government guided groups in the field of cooperatives and small businesses.

As explained at the beginning, COVID-19 has had a multidimensional impact on all community activities, from health, social, to economic. Respect government policies limiting community mobility by implementing Large-Scale Social Restrictions in several densely populated areas; people are encouraged to stay at home more (Haider Syed et al., 2020). It has resulted in many of the lowest businesses being laid off. Not only big companies but also SMEs have been hit. Many businesses are forced to go out of business because it is difficult to survive this time. Although many businesses have closed, and employees have been laid off, some are still creative and rise to open new businesses by taking advantage of this condition. One of them is a small business venture. On this basis, the government remains committed to encouraging them with a small funding policy and management guidance so that the government's presence helps them.

\section{Conclusion}

The main objective of this business study is to understand the funding policies and encouragement of small business management to raise micro, small and medium enterprises (MSMEs) after the COVID-19 crisis in Indonesia. The fate of small businesses, especially funding and management, is experiencing severe obstacles, and it is predicted that they will rise if the government is concerned about recovery, both during the painful period of the pandemic and in 2021, along with the decline in the contents of the coronavirus reported both at home and abroad. After a series of data searches, then continued to analyze. Considering data review and other related information sources, we can conclude that funding and support for small business units' operational management towards recovery efforts have received a series of supports both in funds and other policy strategies. The conclusions and findings of the publications that we have reviewed have shown the seriousness of each country's governments and local governments to seriously support small business units so that they can continue both during the pandemic and postCOVID-19. Thus, we can conclude that the findings of this small and medium business study are significant input for the government of each country and become the next study material for those who want to explore studies in midwives, the efforts of each government to support the small economy after they have been hit by disturbances and multiple financial crises since the COVID pandemic-19 penetrated and hit the world economy.

\section{Acknowledgments}

We thank our colleagues and professors who have contributed to the discussion and feedback from the beginning to the completion of this paper. Likewise, the coauthors with the ideas and support of the writing process until this work was completed on time with the topic of their study "Analyzing Financial and Management Support to Restore Micro, Small and Medium Enterprises (MSMEs) after the COVID-19 Pandemic in Indonesia. For cooperation with us, thank you. 


\section{References}

Arend, R. J., \& Wisner, J. D. (2005). Small business and supply chain management: is there a fit?. Journal of Business Venturing, 20(3), 403-436. https://doi.org/10.1016/j.jbusvent.2003.11.003

Aslan, A., Silvia, S., Nugroho, B. S., Ramli, M., \& Rusiadi, R. (2020). Teacher's Leadership Teaching Strategy Supporting Student Learning During the COVID-19 Disruption. Nidhomul Haq: Jurnal Manajemen Pendidikan Islam, 5(3), 321-333.

Blandina, S., Fitrian, A. N., \& Septiyani, W. (2020). Strategi Menghindarkan Indonesia dari Ancaman Resesi Ekonomi di Masa Pandemi. Efektor, 7(2), 181-190.

Fanelli, D. (2009). How many scientists fabricate and falsify research? A systematic review and meta-analysis of survey data. PloS one, 4(5), e5738.

Febriana, D. T. (2017). Peranan Pemerintah Daerah dalam PemberdayaanUKM di Desa Sukamulya Kecamatan Banyumas Kabupaten PringsewuPerspektif Ekonomi Islam (Studi pada Kelompok Usaha Bersama (KUBE) Kain Perca desa Sukamulya Binaan Dinas Koperindag Kabupaten Pringsewu) (Doctoral dissertation, UIN Raden Intan Lampung).

Goniewicz, K., Khorram-Manesh, A., Hertelendy, A. J., Goniewicz, M., Naylor, K., \& Burkle, F. M. (2020). Current response and management decisions of the European Union to the COVID-19 outbreak: a review. Sustainability, 12(9), 3838.

Haddud, A., DeSouza, A., Khare, A., \& Lee, H. (2017). Examining potential benefits and challenges associated with the Internet of Things integration in supply chains. Journal of Manufacturing Technology Management.

Hadi, A., Handajani, L., \& Putra, I. N. N. A. (2018). Financial disclosure based on Web-ICT determinants: its implications for local government financial performance in Indonesia. International research journal of management, IT and social sciences, 5(1), 72-85.

Haider Syed, M., Khan, S., Raza Rabbani, M., \& Thalassinos, Y. E. (2020). An artificial intelligence and NLP based Islamic FinTech model combining Zakat and Qardh-Al-Hasan for countering the adverse impact of COVID 19 on SMEs and individuals.

Hansemark, O. C. (2003). Need for achievement, locus of control and the prediction of business start-ups: A longitudinal study. Journal of economic Psychology,24(3), 301-319. https://doi.org/10.1016/S01674870(02)00188-5

Humphery, O., \& Freeman, O. O. (2018). SMES financing and its effects on Nigerian economic growth.

Kauffmann, C. (2005). Financing SMEs in Africa.

Kumar, R., Singh, R. K., \& Shankar, R. (2015). Critical success factors for implementation of supply chain management in Indian small and medium enterprises and their impact on performance. IIMB Management review, 27(2), 92-104. https://doi.org/10.1016/j.iimb.2015.03.001

Marlinah, L. (2020). Peluang dan Tantangan UMKM Dalam Upaya Memperkuat Perekonomian Nasional Tahun 2020 Ditengah Pandemi Covid 19. Jurnal Ekonomi, 22(2), 118-124

Moser, C. A., \& Yared, P. (2020). Pandemic lockdown: The role of government commitment (No. w27062). National Bureau of Economic Research.

Muhyiddin, M. (2020). Covid-19, New Normal, dan Perencanaan Pembangunan di Indonesia. Jurnal Perencanaan Pembangunan: The Indonesian Journal of Development Planning, 4(2), 240-252.

Napitupulu, D., Syafrullah, M., Rahim, R., Abdullah, D., \& Setiawan, M. I. (2018, April). Analysis of user readiness toward ICT usage at small medium enterprise in south tangerang. In Journal of Physics: Conference Series (Vol. 1007, No. 1, p. 012042). IOP Publishing.

Nasution, L. (2020). Efektifitas HKI Sebagai Pelindung Industri Kreatif dan UMKM Di Tengah Pandemi Covid19. 'ADALAH, 4(1).

Pakpahan, A. K. (2020). Covid-19 Dan Implikasi Bagi Usaha Mikro, Kecil, Dan Menengah. Jurnal Ilmiah Hubungan Internasional, 59-64.

Putra, P., Liriwati, F. Y., Tahrim, T., Syafrudin, S., \& Aslan, A. (2020). The students learning from home experiences during Covid-19 school closures policy in Indonesia. Jurnal Iqra': Kajian Ilmu Pendidikan, 5(2), 3042.

Razumovskaia, E., Yuzvovich, L., Kniazeva, E., Klimenko, M., \& Shelyakin, V. (2020). The Effectiveness of Russian Government Policy to Support SMEs in the COVID-19 Pandemic. Journal of Open Innovation: Technology, Market, and Complexity, 6(4), 160.

Rowan, N. J., \& Galanakis, C. M. (2020). Unlocking challenges and opportunities presented by COVID-19 pandemic for cross-cutting disruption in agri-food and green deal innovations: Quo Vadis?. Science of the Total Environment, 141362. https://doi.org/10.1016/j.scitotenv.2020.141362 
Saputri, M. A., \& Wijaya, T. (2018). Pengaruh Tingkat Literasi Keuangan Terhadap Pengelolaan Keuangan Pada Pelaku UMKM Kecamatan Mojolaban Kabupaten Sukoharjo [PhD Thesis]. IAIN Surakarta.

Setyawan, W., \& Wulandari, S. (2020). Perilaku Manajemen Keuangan Mahasiswa Kelas Karyawan Di Cikarang. Jurnal Ilmu Manajemen Dan Bisnis, 11(1), 47-60.

Shafi, M., Liu, J., \& Ren, W. (2020). Impact of COVID-19 pandemic on micro, small, and medium-sized Enterprises operating in Pakistan. Research in Globalization, 2, 100018. https://doi.org/10.1016/j.resglo.2020.100018

Singh, S., Kumar, R., Panchal, R., \& Tiwari, M. K. (2020). Impact of COVID-19 on logistics systems and disruptions in food supply chain. International Journal of Production Research, 1-16.

Sondakh, O. (2019, June). Measuring the Organizational Innovation Capabilities (A case study of SMEs Food Industry in Surabaya-Indonesia). Information and Knowledge Management.

Sugiri, D. (2020). Menyelamatkan usaha mikro, kecil dan menengah dari dampak pandemi Covid-19. Fokus Bisnis: Media Pengkajian Manajemen dan Akuntansi, 19(1), 76-86.

Taiwo, J. N., Falohun, T. O., \& Agwu, P. E. (2016). SMEs financing and its effects on Nigerian economic growth. European Journal of Business, Economics and Accountancy, 4(4).

Thaha, A. F. (2020). Dampak covid-19 terhadap UMKM di Indonesia. BRAND Jurnal Ilmiah Manajemen Pemasaran, 2(1), 147-153.

Wu, W. W. (2010). Beyond business failure prediction. Expert systems with applications, 37(3), 2371-2376. https://doi.org/10.1016/j.eswa.2009.07.056

Wu, Z., Chua, J. H., \& Chrisman, J. J. (2007). Effects of family ownership and management on small business equity financing. Journal of business venturing, 22(6), 875-895. https://doi.org/10.1016/j.jbusvent.2006.07.002 